\title{
Fraud Diamond dan Deteksi Kecurangan Laporan Keuangan Perusahaan Food and Beverage di Bursa Efek Indonesia
}

\author{
Rasiman ${ }^{1}$, Widarto Rachbini ${ }^{2}$ \\ ${ }^{1.2}$ Universitas Pancasila, Jl. Srengseng Sawah, Jagakarsa, Jakarta Selatan, 12640
}

\author{
INFO ARTIKEL \\ JEL Classsification: \\ M40 \\ M48
}

Keywords:

fraud diamond, financial statement fraud, earning management, auditor changes, director changes

\section{ABSTRACT}

The development of the national economy in the foreseeable future still shows uncertainty due to increasing competition in the business world. The food and beverage industry also has an important role in the development of the industrial sector. Its contribution to the Gross Domestic Product (GDP) of the non-oil industry is the largest compared to other subsectors which reached 33.6 percent in the third quarter of 2016. This research is to test and analyze the influence of diamond fraud factors (pressure, opportunity, rationalization and capability) against financial statement fraud. This study uses secondary data. The research sample was a Food and Beverage company listed on the Indonesia Stock Exchange in the period 2012 to 2016, with a total sample of 60. The sample method used was the documentation and literature. This study uses Partial Least Squares (PLS) version 3.0 for processing data with the results of the study showing that the pressure variable is measured by indicators of financial stability, opportunity variables as measured by the nature of industry, rationalization variables measured by auditor changes and capability variables measured by director changes affect financial statement fraud.

\begin{abstract}
ABSTRAK
Perkembangan ekonomi nasional dalam beberapa waktu kedepan masih menunjukkan ketidakpastian akibat dari semakin ketatnya persaingan di dunia bisnis. Industri makanan dan minuman juga mempunyai peranan penting dalam pembangunan sektor industri. Kontribusinya terhadap Produk Domestik Bruto (PDB) industri non migas merupakan yang terbesar dibandingkan subsektor lainnya yang mencapai 33,6 persen pada triwulan III pada tahun 2016. Penelitian ini adalah menguji dan menganalisis pengaruh faktorfaktor fraud diamond (pressure, opportunity, rationalization dan capability) terhadap financial statement fraud. Penelitian ini menggunakan data sekunder. Sampel penelitian adalah perusahaan Food and Beverage yang terdaftar di Bursa Efek Indonesia pada periode 2012 sampai 2016, dengan jumlah sampel sebanyak 60. Metode sampel yang digunakan penelitian adalah dokumentasi dan kepustakaan. Penelitian ini menggunakan Partial Least Squares (PLS) versi 3.0 untuk pengolahan data dengan hasil penelitian menunjukan bahwa variabel pressure yang diukur dengan indikator financial stability, variabel opportunity yang diukur dengan nature of industry, variabel rationalization yang diukur dengan auditor changes dan variabel capability yang diukur dengan director changes berpengaruh terhadap financial statement fraud.
\end{abstract}

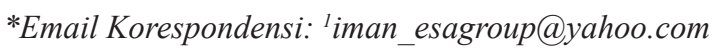




\section{Pendahuluan}

Industri makanan dan minuman juga mempunyai peranan penting dalam pembangunan sektor industri. Kontribusinya terhadap Produk Domestik Bruto (PDB) industri non migas merupakan yang terbesar dibandingkan subsektor lainnya yang mencapai 33,6 persen pada triwulan III 2016. Dengan pertumbuhan 9,82 persen, sektor ini menopang sebagian besar pertumbuhan industri non migas dengan pertumbuhan mencapai 4,71 persen. Sementara itu, sumbangan nilai ekspor produk makanan dan minuman termasuk minyak kelapa sawit pada Januari-September 2016 mencapai US\$ 17,86 miliar. Capaian ini membuat neraca perdagangan masih positif bila dibandingkan dengan nilai impornya pada periode yang sama sebesar US\$ 6,81 miliar (www.msn.com).

Peneliti mencoba melakukan penelitian untuk mendeteksi adanya kecurangan laporan keuangan (fraudulent financial statement) berdasarkan pada data pertumbuhan industri pengolahan non migas, khususnya disektor makanan dan minuman (food and beverage) yang mengalami pertumbuhan tertinggi dengan mengadopsi penelitian Kusumaningrum dan Murtanto (2016) yang bertujuan untuk menguji dan menganalisis pengaruh fraud risk factor menurut fraud diamond yaitu pressure, opportunity, rationalization dan cappability terhadap financial statement fraud. Penelititan tersebut menggunakan sepuluh indikator variabel independen yaitu financial stability, external pressure, personal financial needs, financial target, nature of industry, innefective monitoring, organizational struc-ture, rationalization, positioning dan inteli-gence. Adapun sampel yang digunakan adalah perusahaan perbankan yang terdaftar di Bursa Efek Indonesia pada periode 2010-2014.

Variabel-variabel ini diukur dengan eckel index. hasil penelitian ini menunjukan variabel external pressure yang diproksikan dengan debt ratio, personal financial needs yang diproksikan

dengan insiders stock ownership, nature of industry yang diproksikan dengan loan to debt ratio, ineffective monitoring diproksikan dengan ineffective antifraud program and training; ineffective whistleblowing system, organizational structure yang diproksikan dengan direction changes terbukti berpengaruh terhadap financial statement fraud. Penelitian ini dilakukan untuk meneliti faktor-faktor yang masih belum konsisten dari penelitian sebelumnya untuk mempengaruhi seseorang dalam melakukan fraud.

Pada penelitian ini menggunakan empat variabel independen dengan delapan indikator yaitu pressure yang diproksikan dengan financial target, financial stability, personal financial need dan external pressure, opportunity yang diproksikan dengan nature of industry, rationalization yang diproksikan dengan total accrual dan audit changes, dan capability yang diproksikan dengan director changes dan satu variabel dependen yaitu financial statement fraud yang diproksikan dengan earning management. Periode pengamatan yang dilakukan selama lima tahun dari tahun 2012-2016 dengan sampel perusahaan makanan dan minuman yang terdaftar di Bursa Efek Indonesia. Berikut fenomena yang melakukan earning management pada perusahaan food and beverage dalam kurun waktu 2012-2016.

Pada tahun 2012 mayoritas perusahaan food and beverage melakukan manajemen laba dengan cara menurunkan laba perusahaan sebanyak delapan perusahaan, sedangkan sebanyak empat perusahaan melakukan manajemen laba dengan cara menaikkan laba perusahaan. Tahun 2013 sebanyak tujuh perusahaan yang melakukan manajemen laba dengan cara menaikkan laba perusahaan dan sisanya sebanyak lima perusahaan melakukan manajemen laba dengan cara menurunkan laba perusahaan.

Tahun 2014 sebanyak enam perusahaan yang melakukan manajemen laba dengan cara 
menaikkan laba perusahaan dan sebanyak enam perusahaan juga yang melakukan manajemen laba dengan cara menurunkan laba perusahaan. Tahun 2015 sebanyak sepuluh perusahaan yang melakukan manajemen laba dengan cara menurunkan laba perusahaan dan sisanya dua perusahaan melakukan manajemen laba dengan cara menaikkan laba perusahaan. Tahun 2016 sebanyak lima perusahaan melakukan manajemen laba dengan cara menaikkan laba perusahaan dan mayoritas sebanyak tujuh perusahaan melakukan manajemen laba dengan cara menurunkan laba perusahaan.

\section{Telaah Teori dan Pengembangan Hipotesis}

Teori keagenan menurut Fahmi (2014:1920), agency theory (teori keagenan) merupakan suatu kondisi yang terjadi pada suatu perusahaan dimana pihak manajemen sebagai pelaksana yang disebut lebih jauh sebagai agen dan pemilik modal (owner) sebagai prinsipal membangun sebuah kontrak kerjasama yang disebut dengan "nexus of contract", kontrak kerjasama ini berisi kesepakatan-kesepakatan yang menjelaskan bahwa pihak manajemen perusahaan harus bekerja secara maksimal untuk memberi kepuasan yang maksimal seperti profit yang tinggi kepada pemilik modal (owner).

Menurut Islahuzzaman (2012:257) mendefinisikan manajemen laba adalah sebagai berikut : "Manajemen Laba adalah proses penyusunan laporan keuangan bagi pihak eksternal sehingga dapat meratakan, menaikkan dan menurunkan laporan laba, dimana manajemen dapat menggunakan kelonggaran penggunaan metode akuntansi."

Dari pengertian diatas dapat dikatakan bahwa manajemen laba adalah suatu penyusunan laporan yang sengaja dilakukan oleh manajemen yang ditujukan pada pihak eksternal dengan cara meratakan, menaikkan dan menurunkan laporan laba untuk memperoleh beberapa keuntungan pribadi.
Menurut Priantara (2013:68) Fraudulent financial statement adalah penyajian kondisi financial suatu perusahaan yang disengaja salah yang dapat tercapai melalui salah saji yaitu penghilangan sejumlah nilai dilaporan keuangan yang bertujuan untuk mengelabui pengguna laporan keuangan yang identik dilakukan oleh manajemen, sebab mayoritas pelaku memang berada pada tingkat atau kedudukan lini manajerial (pejabat, eksekutif senior dan manager senior). Manajemen dapat menutupi kondisi keuangan perusahaan yang sebenarnya dengan melakukan rekayasa keuangan (financial engineering) guna untuk memperoleh keuntungan atau manfaat pribadi terkait dengan kedudukan dan tanggungjawabnya.

Fraud triangle adalah konsep yang menggambarkan faktor-faktor yang menyebabkan terjadinya fraudulent. Konsep dari fraud triangle diperkenalkan dalam literatur profesional pada Statement of Auditing Standard (SAS) No.99 dari American Institute of Certified Public Accountant (AICPA) yang merevisi SAS No.82 "Consideration of Fraudinal Financial Statement Audit" yang disebutkan contoh dan faktor-faktor risiko fraud. SAS No. 99 telah mengkaitkan faktor risiko fraud dengan segitiga fraud yang bertumpu pada riset yang dilakukan Schuchter dan Levi (2016). Schuchter dan Levi (2016) menyimpulkan bahwa fraud secara umum mempunyai tiga sifat. Fraud triangle terdiri dari tiga kondisi tekanan, peluang, dan rasionalisasi.

Tekanan adalah suatu kondisi yang ditujukan kepada individu atau sekelompok orang yang dapat mengubah tingkah laku individu tersebut. Dalam perspektif fraud, tekanan adalah kondisi yang mendorong seseorang untuk melakukan fraud. Tekanan dapat mencakup hampir semua hal termasuk gaya hidup atau life style, tuntutan ekonomi, dan lingkungan individu berada. Peluang adalah suatu kondisi yang memberikan kemungkinan seseorang untuk berbuat atau menempati suatu tempat pada posisi tertentu. Dalam fraud triangle, peluang merupakan suatu kesempatan seseorang untuk melakukan fraud 
Priantara, (2013). Peluang dapat terjadi karena pengendalian internal yang lemah, manajemen pengawasan yang kurang baik dan penggunaan posisi atau jabatan yang dapat memberikan keuntungan pribadi. Rasionalisasi berdasarkan perspektif fraud triangle adalah pembenaran atas suatu aktivitas yang mengandung fraud Priantara, (47:2013). Alasan-alasan yang diberikan dalam rasionalisasi adalah bentuk yang tidak sebenarnya dan dipengaruhi dengan adanya kepentingan pribadi seseorang ketimbang kebenaran itu sendiri. Rasionalisasi menjadi elemen penting dalam terjadinya fraud, dimana pelaku mencari pembenaran atas perbuatannya. Rasionalisasi merupakan bagian dari fraud triangle yang paling sulit diukur. Karena rasionalisasi ada dalam sifat perilaku yang dimiliki individu tersebut. Seperti individu yang umumnya tidak jujur, mungkin mereka lebih mudah untuk merasionalisasi fraud. Dan sebaliknya bagi mereka yang amanah, jujur dan memiliki standar moral yang tinggi, mereka tidak mudah goyah untuk melakukan fraud.

Fraud diamond adalah konsep yang dapat digunakan untuk meningkatkan pencegahan dan deteksi fraud dengan mempertimbangkan elemen yang keempat selain tekanan, peluang dan rasionalisasi yaitu mempertimbangkan kemampuan individu, Priantara (2013:47). Banyak penelitian menunjukan bahwa terjadinya fraud terjadi ketika seseorang mengalami pressure (tekanan) dan opportunity (kesempatan). Pengawasan lemah memberikan kesempatan bagi orang-orang untuk melakukan fraud dan orang tersebut merasionalisasi perilaku fraud-nya Priantara (2013:47). Fraud tidak akan terjadi tanpa adanya keberadaan orang yang tepat dengan kemampuan yang tepat. Peluang membuka pintu fraud, tekanan dan rasionalisasi dapat menarik orang untuk melakukan fraud Priantara (2013:47). Akan tetapi semua ini tidak akan terjadi tanpa adanya seseorang yang memiliki kemampuan untuk mengenali peluang sebagai sebuah kesempatan dan mengambil keuntungan tersebut. Kemampuan individu adalah sifat dan kemampuan pribadi seseorang yang memainkan peran besar yang memungkinkannya terjadi suatu tindakan. Dalam fraud diamond, konsep ini mempertimbangkan kemampuan individu untuk menjadi orang yang tepat dalam melakukan fraud. Individu tersebut harus memiliki kemampuan untuk mengenali peluang sebagai sebuah kesempatan dan mengambil keuntungan tersebut Priantara (2013:48).

\section{Hubungan Tekanan dengan Financial Statement Fraud}

Manajemen seringkalimendapatkan tekanan untuk menunjukkan bahwa perusahaan telah mampu mengelola aset dengan baik sehingga laba yang dihasilkannya juga banyak dan nantinya akan menghasilkan return yang tinggi pula untuk investor. Dengan alasan demikian, manajemen memanfaatkan laporan keuangan sebagai alat untuk menutupi kondisi stabilitas keuangan yang buruk dengan melakukan fraud. Penelitian yang dilakukan oleh Iqbal dan Murtanto (2015), Widarti (2015), Marfuah (2015), Annisya, dkk, menunjukkan bahwa persentase perubahan total aset ( $A C H A N G E$ ) berpengaruh positif terhadap financial statement fraud.

External pressure merupakan tekanan yang berlebihan bagi manajemen untuk memenuhi persyaratan atau harapan dari pihak ketiga. Menurut SAS No. 99, saat tekanan berlebihan dari pihak eksternal terjadi, maka terdapat resiko kecurangan terhadap laporan keuangan. Hal ini didukung oleh pendapat Iqbal dan Murtanto (2015) yang menyatakan bahwa salah satu tekanan yang seringkali dialami manajemen perusahaan adalah kebutuhan untuk mendapatkan tambahan utang atau sumber pembiayaan eksternal agar tetap kompetitif, termasuk pembiayaan riset dan pengeluaran pembangunan atau modal. Penelitian yang dilakukan oleh Widarti (2015), Maghfiroh, dkk (2015), Pasmaulida (2016), external pressure (FREEC) ber-pengaruh positif terhadap financial 
statement fraud. Marfuah (2015), Annisya, dkk (2016), Aghghaleh, dkk (2014) external pressure ( $L E V)$ berpengaruh positif terhadap financial statement fraud. Kusumaningrun dan Murtanto (2016), external pressure (Debt Ratio) berpengaruh positif terhadap financial statement fraud.

Personal financial need merupakan suatu kondisi ketika keuangan perusahaan turut dipengaruhi oleh kondisi keuangan para eksekutif perusahaan Iqbal dan Murtanto (2015). Ketika eksekutif perusahaan memiliki peranan keuangan yang kuat dalam perusahaan, personal financial need dari eksekutif perusahaan tersebut akan turut terpengaruh oleh kinerja keuangan perusahaan.

Adanya kepemilikan saham oleh orang dalam perusahaan menyebabkan yang bersangkutan merasa punya hak klaim atas penghasilan dan aktiva perusahaan sehingga akan mempengaruhi kondisi keuangan perusahaan. Ketidakjelasan pemisahan antara pemilik dan kontrol dari perusahaan memicu para manajer sewenang-wenang menggunakan dana perusahaan untuk kepentingan pribadi. Contoh kepentingan pribadi yang merupakan tekanan yang dialami para manajer yang akan mendorong terjadinya kecurangan laporan keuangan antara lain tekanan keuangan, tekanan kebiasaan buruk dan tekanan berkaitan dengan pekerjaan.

Semakin tinggi persentase kepemilikan saham oleh orang dalam maka praktek fraud dalam memanipulasi laporan keuangan semakin bertambah. Penelitian yang dilakukan oleh Kusumaningrum dan Murtanto (2016) menunjukkan bahwa persentase kepemilikan saham oleh orang dalam (Insiders stock ownership) berpengaruh positif terhadap financial statement fraud.

Financial targetadalah risiko adanya tekanan berlebihan pada manajemen untuk mencapai target keuangan yang dipatok oleh direksi atau manajemen, termasuk tujuan- tujuan penerimaan insentif dari penjualan maupun keuntungan. Iqbal dan Murtanto (2015) mengatakan bahwa Return on asset (ROA) sering digunakan dalam menilai kinerja manajer dan dalam menentukan bonus, kenaikan upah, dan lain-lain.

Semakin tinggi $R O A$ yang ditargetkan perusahaan, maka semakin rentan manajemen akan melakukan manipulasi laba yang menjadi salah satu bentuk kecurangan sehingga memiliki hubungan positif dengan kecurangan laporan keuangan. Penelitian yang dilakukan oleh Widarti (2015), Kusumaningrum dan Murtanto (2016), financial target (ROA) berpengaruh positif terhadap financial statement fraud. Berdasarkan uraian tersebut, diajukan hipotesis sebagai berikut:

Hipotesis 1 : Pressure berpengaruh positif terhadap Financial Statement Fraud.

\section{Hubungan Nature of Industry dengan Financial Statement Fraud}

Nature of industry merupakan keadaan ideal suatu perusahaan dalam industri. Pada laporan keuangan terdapat akun-akun tertentu yang besarnya saldo ditentukan oleh perusahaan berdasarkan suatu estimasi, misalnya akun piutang tak tertagih dan akun persediaan usang. Iqbal dan Murtanto (2015) juga menyatakan bahwa manajer akan fokus terhadap kedua akun tersebut jika berniat melakukan manipulasi pada laporan keuangan. Penelitian yang dilakukan oleh Marfuah (2015), ineffective monitoring berpengaruh positif terhadap financial statement fraud, Rachmawati dan Marsono (2014), organization structure (CROSSDIR) berpengaruh positif terhadap financial statement fraud, Cicilia, dkk (2015), efektivitas pengawasan (IND) berpengaruh positif terhadap financial statement fraud, Kusumaningrum dan Murtanto (2016), nature of industry (LDR), ineffective monitoring (ineffective antifraud and training; ineffectiveve whistleblowing system) 
berpengaruh positif terhadap financial statement fraud, Zaky (2017), ineffective monitoring (IDDE) berpengaruh positif terhadap financial statement fraud. Berdasarkan uraian tersebut, diajukan hipotesis sebagai berikut:

Hipotesis 2: Opportunity mempunyai pengaruh positif terhadap Financial Statement

Fraud.

\section{Hubungan Opportunity dengan Financial Statement Fraud}

Rasionalisasi adalah bagaimana membenarkan pikirannya dalam melakukan tindakan kejahatan. Rasionalisasi adalah faktor yang sulit untuk diukur untuk mendeteksi kecurangan seperti manajemen laba. Manajemen laba adalah proses pembuatan keputusan manajemen yang membuka jalan terhadap dorongan atau pemahaman manajemen atas istilah yang mungkin menuntun pada kecurangan laporan keuangan.

Hanya saja auditor lebih mentolerir usaha klien untuk mengelola laba dari waktu ke waktu yaitu pihak auditor eksternal perlu mengidentifikasi dan mempertimbangkan faktor-faktor risiko yang menyebabkan klien audit mereka melakukan tindakan kecurangan. Auditor dapat memberikan beberapa opini atas perusahaan yang diauditnya sesuai dengan kondisi yang terjadi pada perusahaan tersebut. Salah satu opini auditor yang diberikan adalah wajar tanpa pengecualian dengan bahasa penjelas. Opini tersebut merupakan bentuk tolerir dari auditor atas manajemen laba.

Hal ini memungkinkan manajemen untuk bersikap rasionalisasi atau menganggap kesalahan yang dibuatnya tidaklah salah, dikarenakan telah ditolerir oleh auditor melalui bahasa penjelas tersebut dalam opininya. Penelitian yang dilakukan oleh Iqbal dan Murtanto (2016), rationalization (TACC) berpengaruh positif terhadap financial statement fraud, Widarti (2015), rationalization (AUDITREPORT) berpengaruh positif terhadap financial statement fraud, Rahmawati dan Marsono (2014), penggantian auditor (CPA) berpengaruh positif terhadap financial statement fraud. Berdasarkan uraian tersebut, diajukan hipotesis sebagai berikut:

Hipotesis 3 : Rationalization berpengaruh positif terhadap Financial Statement Fraud.

\section{Hubungan Rationalization dengan Financial Statement Fraud}

Faktor-faktor yang mempengaruhi seseorang melakukan kecurangan, dengan elemen kemampuan (capability). Penipuan tidak akan terjadi tanpa orang yang tepat dengan kemampuan yang tepat untuk melaksanakan setiap detail dari penipuan. Capability artinya upaya seseorang dalam melakukan tindak kecurangan demi tercapainya tujuan tertentu.

Adapun sifat-sifat yang dijelaskan terkait elemen kemampuan (capability) dalam tindakan pelaku kecurangan yaitu capability seperti: position/function, brains, confidence/ ego, coercion skills, effective lying dan immunity to stress. Berdasarkan sifat - sifat yang dikemukakan tersebut, maka posisi $C E O$, direksi, maupun kepala divisi lainnya menjadi yang paling sesuai dengan karakteristik tersebut. Posisi $C E O$, direksi, maupun kepala divisi lainnya dapat menjadi faktor penentu terjadinya kecurangan, dengan memanfaatkan posisinya yang dapat memengaruhi orang lain guna memperlancar tindakan kecurangannya.

Perubahan direksi adalah penyerahan wewenang dari direksi lama kepada direksi baru dengan tujuan untuk memperbaiki kinerja manajemen sebelumnya. Namun, perubahan direksi dapat menimbulkan stress period sehingga berdampak pada semakin terbukanya peluang untuk melakukan fraud. Rahardjo (2014) menggunakan perubahan direksi sebagai proksi dari capability (kemampuan) untuk mengetahui indikasi terjadinya financial statement fraud. Perubahan direksi dapat menimbulkan kinerja awal yang tidak maksimal karena mem 
butuhkan waktu untuk beradaptasi Rahardjo (2014). Berdasarkan uraian tersebut, penelitian ini mengajukan hipotesis sebagai berikut:

Hipotesis 4: Capability berpengaruh positif terhadap Financial Statement Fraud.

\section{Metode Penelitian}

Desain penelitian yang digunakan adalah penelitian kausal yang merupakan penelitian yang bertujuan untuk mengetahui hubungan antara dua variabel atau lebih Sugiyono (2016:56). Penelitian kausal ini merupakan penelitian untuk mengetahui pengaruh antara satu atau lebih variabel bebas (independen variable) terhadap variabel terikat (dependen variable). Variabel-variabel yang akan diuji signifikansi pengaruhnya adalah financial stability, external pressure, personal financial need, financial target, nature of industry, organizational structure, rationalization, dan audit report (variabel independen), terhadap earning management (variable dependen) pada perusahaan food and beverage periode 20122016.

Metode pengumpulan data yang digunakan dalam penelitian ini adalah dokumentasi dan kepustakaan. Metode dokumentasi yaitu teknik pengumpulan data dengan cara melihat, menggunakan, dan mempelajari data-data sekunder yaitu dengan melakukan pengambilan data laporan tahunan perusahaan food and beverage tahun 2012 sampai dengan $2016 \mathrm{di}$ Bursa Efek Indonesia (BEI) yang diperoleh dari website www.idx.co.id.

Agar memperoleh hasil penelitian yang diharapkan, dibutuhkan data dan informasi yang akan mendukung penelitian ini, maka digunakan teknik pengumpulan data penelitian kepustakaan (library research). Penelitian kepustakaan dilakukan dengan cara mengumpulkan data yang terdapat kaitan dengan objek pembahasan yaitu dengan mempelajari buku-buku wajib, artikel, jurnal-jurnal ilmiah yang berhubungan dengan penelitian ini.
Data yang digunakan dalam penelitian ini adalah data sekunder. Data sekunder adalah data yang diperlukan untuk mendukung hasil penelitian berasal dari literatur, artikel dan berbagai sumber lainnya yang berhubungan dengan penelitian Sugiyono (2016:137). Sumber data yang digunakan dalam penelitian ini diperoleh dari laporan keuangan periode 31 Desember 2012-2016 yang telah diaudit yang telah tersusun dalam laporan keuangan tahunan yang diperoleh di situs internet yaitu www.idx. co.id pada periode pengamatan tahun 20122016.

Populasi yang diambil oleh peneliti adalah laporan keuangan tahunan (annual report) seluruh sub sektor food and beverage yang terdaftar di Bursa Efek Indonesia periode 20122016. Sampel adalah bagian dari jumlah dan karakteristik yang dimiliki oleh populasi tersebut Sugiyono (2016:81). Sampel yang digunakan dalam penelitian ini diambil menggunakan teknik purposive sampling yaitu sampel dipilih dengan menggunakan pertimbangan tertentu Sugiyono (2016:85). Adapun kriteria penentuan sampel dalam penelitian ini sebagai berikut :

a. Perusahaan dimaksud terdaftar atau listing di Bursa Efek Indonesia periode 2012-2016

b. Menyampaikan datanya secara lengkap sesuai dengan informasi yang diperlukan yaitu laporan keuangan periode 31 Desember 2012-2016 yang telah diaudit. 
Tabel 1. Operasional Variabel Bebas (Independent)

\begin{tabular}{|c|c|c|c|}
\hline No & Variabel & Peneliti & Operasional Variabel \\
\hline \multirow{2}{*}{1} & \multirow{2}{*}{$\begin{array}{l}\text { Financial } \\
\text { Stability }\end{array}$} & \multirow{2}{*}{$\begin{array}{l}\text { Iqbal dan Murtanto } \\
\text { (2016), Widarti (2015) }\end{array}$} & \multirow{2}{*}{ ACHANGE $=\frac{(\text { Total Aset } \mathrm{t}-\text { Total Aset } \mathrm{t}-1)}{\text { Total Aset } \mathrm{t}}$} \\
\hline & & & \\
\hline 2 & $\begin{array}{l}\text { External } \\
\text { Pressure }\end{array}$ & $\begin{array}{l}\text { Marfuah (2015), } \\
\text { Maghfiroh dkk (2015 }\end{array}$ & $L E V=$ Total Debt $/$ Total Asset \\
\hline \multirow{2}{*}{3} & \multirow{2}{*}{$\begin{array}{l}\text { Personal } \\
\text { Financial } \\
\quad \text { Need }\end{array}$} & \multirow{2}{*}{$\begin{array}{l}\text { Widarti (2015), } \\
\text { Prasmaulida (2016) }\end{array}$} & \multirow{2}{*}{ OSHIP $=\frac{\text { Total saham yang dimiliki oleh orang dalam }}{\text { Total saham biasa yang beredar }}$} \\
\hline & & & \\
\hline 4 & $\begin{array}{l}\text { Financial } \\
\text { Target }\end{array}$ & $\begin{array}{l}\text { Iqbal dan Murtanto } \\
\text { (2016), Widarti (2015 }\end{array}$ & ROA $=\frac{\text { Net income } t}{\text { Total asset } t}$ \\
\hline 5 & $\begin{array}{l}\text { Nature Of } \\
\text { Industry }\end{array}$ & $\begin{array}{l}\text { Iqbal dan Murtanto } \\
\text { (2016), Widarti (2015), } \\
\text { Annisya, dkk (2016) }\end{array}$ & RECEIVABLE $=($ Receivablest/Salest - Receivablest- $1 /$ Salest- 1$)$ \\
\hline 6 & $\begin{array}{l}\text { Director } \\
\text { Changes }\end{array}$ & $\begin{array}{l}\text { Widarti (2015), } \\
\text { Annisya, dkk (2016), } \\
\text { Rachmawati dan } \\
\text { Marsono (2014), } \\
\text { Kusumaningrum dan } \\
\text { Murtanto (2016) }\end{array}$ & $\begin{array}{l}\text { a) Kode } 1 \text { ada perubahan direksi selama tahun } 2012-2016 \text {. } \\
\text { b) Kode } 0 \text { tidak ada perubahan direksi selama tahun 2012-2016. }\end{array}$ \\
\hline 7 & $\begin{array}{l}\text { Rationaliza- } \\
\quad \text { tion }\end{array}$ & $\begin{array}{l}\text { Iqbal dan Murtanto } \\
\text { (2016), Widarti (2015), } \\
\text { Tiffani dan Marfuah } \\
(2015\end{array}$ & TACC $=\frac{\text { Total Akrual } t}{\text { Total Aset } t}$ \\
\hline 8 & $\begin{array}{l}\text { Auditor } \\
\text { Changes }\end{array}$ & $\begin{array}{l}\text { Aghghaleh, dkk } \\
\text { (2014), Abiodun dan } \\
\text { Asamu (2017) }\end{array}$ & $\begin{array}{l}\text { a) Kode } 1 \text { ada perubahan auditor selama tahun } 2012 \text { - } 2016 \text {. } \\
\text { b) Kode } 0 \text { tidak ada perubahan auditor selama tahun 2012-2016. }\end{array}$ \\
\hline 1 & $\begin{array}{c}\text { Earning } \\
\text { Management }\end{array}$ & $\begin{array}{l}\text { Iqbal dan Murtanto } \\
\text { (2016), Widarti (2015, } \\
\text { Maghfiroh dkk }\end{array}$ & $\begin{array}{l}\text { TAC it }=\text { Niit }- \text { CFOit } \\
\text { TACit } / \text { Ait- } 1=\beta 1(1 / \text { Ait- } 1)+\beta 2(\Delta \text { Revt/Ait-1 })+\beta 3(\text { PPEt } / \text { Ait- } 1)+\mathrm{e} \\
\text { NDAit }=\beta 1(1 / \text { Ait- } 1)+\beta 2(\Delta \text { Revt } / \text { Ait-1- } \Delta \text { Rect } / \text { Ait- } 1)+\beta 3(\text { PPEt } / \text { Ait- } 1) \\
\text { DAit }=\text { TACit } / \text { Ait-NDAit }\end{array}$ \\
\hline
\end{tabular}

Sumber : Penelitian terdahulu

Model penelitian dapat digambarkan sebagai berikut:

$$
\mathrm{FSF}=\mathrm{a}+\mathrm{b}_{1} \mathrm{PR}+\mathrm{b}_{2} \mathrm{OP}+\mathrm{b}_{3} \mathrm{RT}+\mathrm{b}_{4} \mathrm{CAP}+\mathrm{e} .
$$

Keterangan :

$$
\begin{aligned}
& \mathrm{FSF}=\text { Financial statement fraud } \\
& \mathrm{PR}=\text { Pressure } \\
& \mathrm{OP}=\text { Opportunity } \\
& \mathrm{RT}=\text { Ratonalization } \\
& \mathrm{CAP}=\text { Capability } \\
& \mathrm{e}=\text { error }
\end{aligned}
$$

Nilai $R$ Square sebesar 0.259 berarti variabilitas konstruk financial statement fraud dapat dijelaskan oleh konstruk pressure, oportunity, rationalization dan capability, dengan interaksinya sebesar $25.9 \%$ dengan sangat terbatas atau sangat lemah. Sedangkan $74.1 \%$ dijelaskan oleh variable lain yang tidak terdapat dalam penelitian ini.

Penilaian goodness of fit diketahui dari nilai $R$ Square Adjusted dimana semakin tinggi nilai $R$ Square Adjusted maka model dapat dikatakan semakin baik atau semakin fit dengan data. Berdasarkan hasil olah data nilai R Square Adjusted diperoleh sebesar 0,205. Hal ini menunjukkan besarnya keragaman dari data 
penelitian yang dapat dijelaskan oleh model penelitian adalah sebesar 20,5\%. Sedangkan sisanya $79,5 \%$ dijelaskan oleh variabel lain yang tidak terdapat dalam penelitian ini. Dengan demikian dari hasil tersebut maka model penelitian ini dapat dinyatakan memiliki goodness of fit yang kurang baik.

\section{Hasil dan Pembahasan}

Statistik deskriptif dari indikator pengukuran financial stability, external pressure, personal financial need, financial target, nature of industry, total accrual dan earning manajement dengan jumlah sampel yang diuji sebanyak 60 item selama kurun waktu penelitian 2012 - 2016. Analisis deskriptif pada penelitian ini menggambarkan deskripsi variabel independen (pressure, opportunity, rationalization, capability) dan variabel dependen financial statement fraud. Deskripsi mencakup nilai maksimum, minimum, rata-rata dan standar deviasi masing-masing variabel.

Deskripsi Variabel Penelitian

\begin{tabular}{lccccc}
\hline Variabel & N & Minimum & Maximum & Mean & $\begin{array}{c}\text { Std. } \\
\text { Deviation }\end{array}$ \\
\hline Financial Stability & 60 & $-1,517$ & 0,959 & 0,11742 & 0,289511 \\
Nature Of Industry & 60 & $-0,208$ & 0,133 & $-0,00763$ & 0,054316 \\
Earning Manajemen & 60 & $-4,422$ & 0,381 & $-0,08747$ & 0,575689 \\
Valid N (listwise) & 60 & & & & \\
\hline
\end{tabular}

Sumber : data olah SPSS 2018

Hasil uji hipotesis olah data yang telah dilakukan hasilnya dapat digunakan untuk menjawab hipotesis penelitian ini. Uji hipotesis pada penelitian ini dilakukan dengan melihat T-Statistics dan P-Values. Hipotesis penelitian ini dapat dinyatakan diterima apabila nilai T-Statistics $>$ dari 1,65 dan P-Values lebih kecil dari $10 \%$. Berikut ini adalah hasil uji hipotesis yang diperoleh dalam penelitian ini melalui inner model.

\begin{tabular}{lccccc}
\hline Variabel & $\begin{array}{c}\text { Original } \\
\text { Sample (O) }\end{array}$ & $\begin{array}{c}\text { Sample } \\
\text { Mean (M) }\end{array}$ & $\begin{array}{c}\text { Standard } \\
\text { Error } \\
(\text { STERR })\end{array}$ & $\begin{array}{c}\text { T Statistics } \\
(\mid \text { O/STERR })\end{array}$ & P Values \\
\hline $\begin{array}{l}\text { Pressure -> Financial } \\
\text { Statemen }\end{array}$ & -0.370 & -0.313 & 0.206 & 1.796 & 0.073 \\
$\begin{array}{l}\text { Oportunity -> Financial } \\
\text { Statemen }\end{array}$ & -0.117 & -0.129 & 0.065 & 1.792 & 0.073 \\
$\begin{array}{l}\text { Rationalization } \\
\text { Financial Statemen }\end{array}$ & -0.214 & -0.227 & 0.101 & 2.126 & 0.034 \\
$\begin{array}{l}\text { Capability -> Financial } \\
\text { Statemen }\end{array}$ & -0.208 & -0.192 & 0.098 & 2.116 & 0.034 \\
\hline
\end{tabular}

Sumber : Output SmartPLS 
Cenderung melakukan financial statement fraud dengan cara menurunkan laba (income minimization) dalam hal ini kebijakan yang dapat diambil dengan cara penghapusan atas barang modal dan aktiva tak berwujud, pembebasan biaya iklan dan riset pengembangan dipercepat dalam upayanya menarik minat investor agar menanamkan modal di perusahaan tersebut sedangkan perusahaan yang memiliki persentase perubahan total aset yang kecil dapat juga melakukan manipulasi laporan keuangan agar stabilitas perusahaannya terlihat baik dengan cara menaikan laba (income maximazation).

Temuan ini sejalan dengan penelitian yang dilakukan oleh Iqbal dan Murtanto (2015), Widarti (2015), Marfuah (2015), Annisya, dkk, menunjukkan bahwa pressure yang diproksikan dengan financial stability berpengaruh terhadap financial statement fraud. Tetapi tidak sejalan dengan hasil penelitian yang dilakukan oleh Maghfiroh, dkk (2015) dan Kusumaningrum dan Murtanto (2016) yang menyatakan bahwa pressure yang diproksikan dengan financial stability tidak berpengaruh terhadap financial statement fraud.

Hasil pengujian hipotesis kedua membuktikan bahwa opportunity yang diproksikan dengan nature of industry berpengaruh terhadap financial statement fraud . Temuan ini menunjukan bahwa opportunity (kesempatan) berkaitan dengan munculnya risiko bagi perusahaan yang berkecimpung di dalam industri yang melibatkan estimasi dan pertimbangan yang signifikan jauh lebih besar. Pada laporan keuangan terdapat akun-akun tertentu yang besarnya saldo ditentukan oleh perusahaan berdasarkan suatu estimasi, misalnya akun piutang tak tertagih dan akun persediaan usang. Pengawasan yang lemah terhadap akun piutang tak tertagih menjadi sebuah kesempatan bagi manajemen untuk melakukan kecurangan. Penelitian ini menununjukan bahwa mayoritas perusahaan melakukan transaksi dengan cara tunai (cash) hal ini dikarenakan dengan rendahnya nilai piutang (receivable) dalam melakukan transaksi penjualanya sehingga perlu adanya pengawasan yang super ketat agar tidak terjadi adanya penyelewengan yang dilakukan oleh pihak-pihak yang terkait dengan penjualan tersebut.

Temuan ini sejalan dengan Kusumaningrum dan Murtanto (2016) yang menyatakan bahwa opportunity yang diproksikan dengan nature of industry berpengaruh terhadap financial Statement fraud. Tetapi tidak sejalan dengan hasil penelitian yang dilakukan oleh Iqbal dan Murtanto (2016), Widarti (2015), Marfuah (2015) Annisya, dkk (2016) serta Rachmawati dan Marsono (2014) yang menyatakan bahwa opportunity yang diproksikan dengan nature of industry tidak berpengaruh terhadap financial statement fraud.

Hasil pengujian hipotesis ketiga membuktikan bahwa rationalization yang diproksikan dengan auditor changes berpengaruh terhadap financial statement fraud. Hasil ini menunjukan bahwa faktor sikap/rasionalisasi anggota dewan, manajemen, atau karyawan yang memungkinkan mereka untuk terlibat dalam dan/atau membenarkan kecurangan pelaporan keuangan.

Hubungan antara perusahaan dengan auditornya penting untuk dianalisis dengan berbagai alasan. Jika terjadi pergantian auditor, mungkin ada alasan baik yang mendorong terjadinya pergantian tersebut. KAP tidak akan begitu mudahnya melepaskan klien dan menghentikan hubungan antara auditor dan auditee yang sebagian besar disebabkan oleh kegagalan klien untuk melakukan pembayaran, ketidaksepahaman yang terjadi diantara auditor dan auditee, dan kecurigaan auditor mengenai adanya kecurangan atau masalahmasalah lainya, atau anggapan auditee bahwa fee audit yang dibebankan tinggi, mungkin tidak mengindikasikan adanya potensi terhadap masalah kecurangan. Fakta bahwa auditor diberhentikan atau mengundurkan diri, serta kesulitan auditor di tahun pertama menemukan adanya kecurangan laporan keuangan, 
memberikan banyak alasan perlunya perhatian khusus ketika terjadi pergantian auditor.

Adanya sifat dasar dari peraturan yang berlaku yaitu salah satu hasil potensial dari adanya standar yang berbasis aturan adalah jika klien dapat menemukan celah dalam peraturan dan mencatat transaksi dengan cara yang tidak secara khusus dilarang oleh standar akuntansi keuangan yang berlaku, maka akan sulit bagi auditor untuk melarang klien tersebut untuk menggunakan metode akuntansi tersebut. Selain itu dalam beberapa kasus (Zimbelman et al., 2015) menyatakan bahwa banyak auditor justru membantu untuk mencari celah tersebut atau memberikan izin kepada klien untuk mencatat transaksi dengan cara yang bertentangan dengan prinsip suatu metode akuntansi, tetapi masih dalam koridor aturan. Hasilnya adalah aturan khusus (atau tidak adanya aturan khusus) yang dimanfaatkan untuk pengaturan-pengaturan keuangan yang baru dan lebih komples sebagai pembenaranuntukmemutuskan praktik akuntansi apa yang bisa diterima dan apa yang tidak bisa diterima. Hasil penelitian menggambarkan bahwa kemungkinan terjadinya pembenaran atas terjadinya kecurangan laporan keuangan sangat tinggi dikarenakan hampir mayoritas perusahaan tidak melakukan pergantian auditor.

Temuan ini sejalan dengan penelitian yang dilakukan oleh Rahmawati dan Marsono (2014), Kusumaningrum dan Murtanto (2016) yang menyatakan bahwa rationalization yang diproksikan dengan auditor changes berpengaruh terhadap financial statement fraud. Tetapi tidak sejalan dengan hasil penelitian yang dilakukan oleh Widarti (2015) dan Annisya, dkk (2016) yang menyatakan bahwa rationalization yang diproksikan dengan auditor changes tidak berpengaruh terhadap financial statement fraud.

Hasil pengujian hipotesis keempat membuktikan bahwa capability yang diproksikan dengan director changes berpengaruh terhadap financial statement fraud. Temuan ini menujukan bahwa terjadinya peristiwa pergantian dewan direksi merupakan salah satu hal yang mengindikasikan bahwa kurang baiknya kemampuan direksi sebagai seorang agen dalam menjalakan tugasnya sehingga pergantian dewan direksi merupakan suatu hal yang dilakukan untuk memperbaiki kinerja yang telah dihasilkan sebelumnya. Sementara perusahaan dengan komposisi dewan direksi yang cenderung tetap mengindikasikan bahwa kemampuan agen dalam mengelola perusahaan lebih baik dan terus dipertahankan. Penelitian ini menggambarkan bahwa sebagian perusahaan melakukan pergantian direksi hal ini dapat menyebabkan ada sress period yang mengakibatkan kemungkinan terjadinya kecurangan sangat terbuka hal ini dikarenakan masih diragukanya kemampuan kinerja dewan direksi yang baru.

Temuan ini sejalan dengan penelitian yang dilakukan Rahardjo (2014) yang menyatakan bahwa capability yang diproksikan dengan director changes berpengaruh terhadap financial statement fraud. Tetapi tidak sejalan dengan hasil penelitian yang dilakukan oleh Kusumaningrum dan Murtanto (2016) dan Zaki (2017) yang menyatakan bahwa capability yang diproksikan dengan director changes tidak berpengaruh terhadap financial statement fraud.

\section{Kesimpulan, Keterbatasan dan Saran}

Berdasarkan hasil analisis data dan pembahasan yang telah dilakukan mengenai faktor-faktor fraud diamond dalam pendeteksian terjadinya financial statement fraud berdasarkan faktor pressure yang diproksikan dengan financial stability, opportunity yang diproksikan dengan nature of industry, rationalization yang diproksikan dengan auditor changes dan capability yang diproksikan dengan director changes pada perusahaan Food and Beverage yang terdaftar di Bursa Efek Indonesia tahun 2012-2016, hasil penelitian bahwa pressure, opportunity, rationalization, dan capability berpengaruh terhadap financial statement fraud pada perusahaanfood and beverage yang terdaftar di Bursa Efek Indonesia tahun 2012-2016, hal ini 
menggambarkan bahwa suatu kondisi keuangan yang stabil sangat berpengaruh terhadap kinerja perusahaan, ketika kondisi keuangan tidak stabil maka berbagai macam cara akan dilakukan oleh manajemen agar kondisi keuangan tetap terlihat stabil diantaranya dengan melakukan kecurangan terhadap laporan keuangan yang diterbitkan.

Implikasi dari hasil penelitian beberapa saran yang dapat disampaikan berdasarkan hasil penelitianiniadalah, penelitian selanjutnyaterkait financial statement fraud dapat menggunakan metode kualitatif dalam metodologi penelitian atau dengan mengkombinasikan metode kualitatif dengan metode kuantitatif. Kelemahan atau bias statistik yang terjadi sebagai efek samping dari metode kuantitatif diharapkan akan ditutupi oleh penggunaan metode kualitatif karena dalam pengukuran Fraud Risk Factor banyak terdapat variabel yang tidak dapat dijelaskan dengan spesifik oleh alat analisis metode kuantitatif seperti pengukuran rationalization dan capability yang akan lebih baik apabila diukur dengan alat analisis metode kualitatif. Penelitian selanjutnya agar dapat menggunakan tata kelola perusahaan yang baik (Good Corparate Governance) sebagai variabel kontrol untuk mencegah terjadinya financial statement fraud.

Perusahaan memiliki tanggung jawab yang besar terhadap penyusunan dan penyajian laporan keuangan perusahaan, berdasarkan penelitian ini dimana masih banyak perusahaan yang memanfaatkan celah dalam laporan keuangan untuk melakukan fraud diharapkan lebih mengetahui dampak dari financial statement fraud karena dimungkinkan akan terjadinya dampak yang lebih serius akibat financial statement fraud.

Pemerintah sebagai pemilik otoritas tertinggi di Indonesia yang diwakili oleh lembaga-lembaga yang berwenang dibawahnya diharapkan mampu untuk lebih peka terhadap kondisi fraud yang semakin berkembang dan memiliki pola yang sulit untuk ditebak dengan cara terus mengawasi dan pembuatan regulasi yang mampu digunakan untuk mencegah terjadinya fraud. Kecurangan atau fraud akan terus terjadi dan berkembang, investor harus mampu mencermati perkembanganya dengan menggunakan indikator-indikator baru dalam kasus fraud sehingga masyarakat atau investor tidak dirugikan dalam melakukan bisnis usahanya.

\section{Daftar Referensi}

Abdillah, W., \& Hartono, J. (2015). Partial Least Square (PLS): alternatif structural equation modeling (SEM) dalam penelitian bisnis. Yogyakarta: Penerbit Andi.

Aghghaleh, S. F., Iskandar, T., \& Mohamed, Z. M. (2014). Fraud risk factors of fraud triangle and the likelihood of fraud occurrence: Evidence from Malaysia. Information Management and Business Review, 6(1), 1-7.

Ananda, H. (2015). Penelitian Bisnis dan Manajemen Menggunakan Partial Least Square (PLS) 3.0. Universitas Brawijaya, Malang.

Annisya, M., Lindrianasari, L., \& Asmaranti, Y. (2016). Pendeteksian Kecurang Laporan Keuangan Menggunakan Fraud Diamond. Jurnal Bisnis dan Ekonomi, 23(1). Aprillia, A., Cicilia, O., \& Sergius, R. P. (2015). The Effectiveness Of Fraud Triangle On Detecting Fraudulent Financial Statement: Using Beneish Model And The Case Of Special Companies. Jurnal Riset Akuntansi dan Keuangan, 3(3), 786-800.

Asare, S. K., Wright, A., \& Zimbelman, M. F. (2015). Challenges facing auditors in detecting financial statement fraud: Insights from fraud investigations. Journal of Forensic \& Investigative Accounting, 7(2), 63-112.

Fahmi, I. (2013). Analisis Laporan Keuangan, bandung: ALFABETA.

Islahuzzaman. 2012. Istilah-istilah Akuntansi 
dan Auditing. Edisi Kesatu. Jakarta : Bumi Aksara.

Iqbal, M. (2016, August). Analisa Pengaruh Faktor-faktor Fraud Triangle Terhadap Kecurangan Laporan Keuangan Pada Perusahaan Property Dan Real Estate Yang Terdaftar Di Bursa Efek Indonesia. In Prosiding Seminar Nasional Cendekiawan (pp. 17-1).

Maghfiroh, N., Ardiyani, K., \& Syafnita, S. (2015). Analisis pengaruh financial stability, personal financial need, external pressure, dan ineffective monitoring pada financial statement fraud dalam perspektif fraud. Jurnal Ekonomi dan bisnis, 16(1).

Murtanto, M., \& Kusumaningrum, A. W. (2016, October). Analisis Pengaruh Fraud Diamond Dalam Mendeteksi Kecurangan Laporan Keuangan. In Seminar Nasional Fakultas Ekonomi UNIBA Surakarta (Vol. 2, No. 1, pp. 125-138).

Nasution, Leni Masnindar. 2017. Statistik Deskriptif. Jurnal Hikmah, Vol 14, No. 1, ISSN : 1829-8419.

Pangesty, S. S., Nuraina, E., \& Sulistyowati, N. W. (2018, October). Pengaruh Fraud Diamond Terhadap Deteksi Kecurangan Laporan Keuangan Pada Perusahaan Manufaktur Yang Terdaftar Di Bei. In FIPA: Forum Ilmiah Pendidikan Akuntansi (Vol. 6, No. 2).

Prasmaulida, S. (2016). Financial Statement Fraud Detection Using Perspective of Fraud Triangle Adopted by SAS No. 99. Asia Pacific Fraud Journal, 1(2), 317-335.

Priantara, D. (2013). Fraud auditing \& investigation. Jakarta: Mitra Wacana Media.
Rachmawati, K. K., \& Marsono, M. (2014). Pengaruh Faktor-Faktor dalam Perspektif Fraud Triangle Terhadap Fraudulent Financial Reporting (Studi Kasus pada Perusahaan Berdasarkan Sanksi dari Bapepam Periode 2008-2012) (Doctoral dissertation, Fakultas Ekonomika dan Bisnis).

Santoso, A., Puspitasari, D., \& Widyaswati, R. (2016). Pengaruh Capital Intencity Ratio, Size, Earning Per Share Eps, Debt To Equity Ratio, Dividen Payout Ratio Terhadap Manajemen Laba. Fokus Ekonomi: Jurnal Ilmiah Ekonomi, 11(1).

Sari, L. P., \& Widyarti, E. T. (2015). Analisis Pengaruh Rasio Keuangan Terhadap Pertumbuhan Laba (Studi Kasus: Perusahaan Food and Beverages yang Terdaftar di Bursa Efek Indonesia periode 2009 sampai dengan 2013) (Doctoral dissertation, Fakultas Ekonomika dan Bisnis).

Schuchter, A., \& Levi, M. (2016). The fraud triangle revisited. Security Journal, 29(2), 107-121.

Sholihin, M., \& Ratmono, D. (2013). Analisis SEM-PLS Dengan WarpPLS 3.0. Yogyakarta: Penerbit Andi.

Umar, H. (2011). Metode Penelitian Skripsi dan Tesis Bisnis.

Zaki, N. M. (2017). The Appropriateness of Fraud Triangle and Diamond Models in Assessing the Likelihood of Fraudulent Financial Statements-An Empirical Study on Firms Listed in the Egyptian Stock Exchange. International Journal of Social Science and Economic Research, 2(0), 2403-2433. 